Jurnal Psikologi Teori dan Terapan

2016, Vol. 7, No. 1, 62-70, ISSN: 2087-1708

\title{
Perbedaan Kemampuan Komunikasi Interpersonal Siswa Kelas Unggulan dan Siswa Reguler
}

\author{
Asteria Lestari Yunianti, dan Meita Santi Budiani \\ Program Studi Psikolog Universitas Negeri Surabaya
}

\begin{abstract}
The aim of this study is to determine the difference in interpersonal communication skills between advanced students and regular students in Shafta Junior High School Surabaya. 196 students from $1^{\text {st }}, 2^{\text {nd }}$ and $3^{\text {rd }}$ grade were involved in this research. These students were divided into two groups of 66 advanced students in one group and 130 regular students in another group. Random Sampling technique was used to recruit subjects of this study. Data collected using a Likert model scale of interpersonal communication scale. Furthermore, Independent Sample Test (t-test) was used to analyse the data. The results shows that the $p$ value is $0.027(<0.05)$, indicating that there is difference in interpersonal communication skills between advanced students and regular students. It can be found from the result that the highest mean value was obtained by advanced students, which means they have higher interpersonal communication skills compared to regular students.
\end{abstract}

Keywords : Interpersonal communication, advanced students, regular students

\begin{abstract}
Abstrak: Penelitian ini bertujuan untuk mengetahui perbedaan kemampuan komunikasi interpersonal siswa unggulan dengan reguler di SMP Shafta Surabaya. 196 siswa dari kelas satu, dua dan tiga terlibat dalam penelitian ini. Subyek dikelompokkan menjadi dua kelompok, 66 siswa unggulan dalam satu kelompok dan 130 siswa reguler dikelompok lainnya. Teknik pengambilan sampel yang digunakan peneliti adalah Simple Random Sampling untuk mengidentifikasi kemampuan komunikasi interpersonal dari dua kelompok tersebut. Penggalian data menggunakan Skala Komunikasi Interpersonal dengan model Likert yang di susun peneliti berdasarkan teori dari Joseph Devito. Analisis data menggunakan uji Independent Sample Test (uji-t). Hasil nilai p sebesar $0,027<0,05$ maka dapat disimpulkan bahwa terdapat perbedaan kemampuan komunikasi interpersonal siswa kelas unggulan dengan siswa reguler. Nilai mean tertinggi diperoleh siswa kelas unggulan yang berarti siswa unggulan memiliki kemampuan komunikasi interpersonal lebih tinggi bila dibandingkan dengan siswa reguler.
\end{abstract}

Kata kunci : Komunikasi interpersonal, siswa unggulan, siswa regular

Manusia adalah makhluk sosial dimana manusia selalu berhubungan dengan manusia lainnya. Mereka selalu ingin tahu dengan apa yang ada disekitar mereka dan apa yang ada didalam dirinya. Rasa ingin tahu inilah yang membuat manusia untuk berkomunikasi. Komunikasi merupakan kebutuhan mendasar dalam kehidupan bermasyarakat. Orang yang tidak dapat berkomunikasi dengan baik cenderung akan terisolisasi atau terasingkan oleh lingkungannya. Kualitas hidup-

Korespondensi tentang artikel ini dapat dialamatkan kepada Asteria L. Yunianti melalui email: asteriyalestari@gmail. 
manusia juga ditentukan oleh pola komunikasi yang dilakukannya. Bahasa memiliki aturan dalam mengatur setiap apa yang disampaikan agar mereka bisa berbahasa secara baik dan benar sehingga komunikasi lebih efektif. Adanya ketegasan dalam komunikasi dapat memberikan respon yang jelas dan positif oleh lawan bicara. Salah satu bentuk yang dapat menentukan keharmonisan antar individu tersebut disebut juga dengan komunikasi interpersonal.

Raymond (Rakhmat, 2009) mendefinisikan komunikasi adalah proses transaksional yang meliputi penyortiran informasi secara kognitif, diseleksi dan pembagian simbol dari informasi yang diterima sebagai cara untuk membantu memperoleh pengalaman dalam mengartikan atau merespon sumber informasi yang diterima (Rakhmat, 2009). Komunikasi merupakan kegiatan yang sangat utama dalam proses interaksi. Mulyana (2005) menyatakan bahwa komunikasi interpersonal adalah komunikasi antara orangorang secara tatap muka, yang memungkinkan setiap pesertanya menangkap reaksi orang lain secara langsung, baik secara verbal maupun nonverbal. Sebuah penelitian (Jawa Pos, 2010) menunjukkan bahwa $70 \%$ waktu jaga manusia dipergunakan untuk berkomunikasi. Hubungan dengan orang lain akan menentukan kualitas hidup seseorang karena dengan komunikasi individu dapat menemukan diri mereka serta menetapkan hubungan dengan dunia sekitar.

Rakhmat (2009) berpendapat bahwa komunikasi membantu pertumbuhan manusia dan komunikasi sangat erat hubungannya dengan perilaku manusia. Adanya aktivitas-aktivitas dalam kehidupan sosial menunjukkan bahwa manusia mempunyai naluri untuk hidup bergaul dengan sesamanya. Naluri ini merupakan salah satu yang paling mendasar dalam kehidupan hidup manusia, disamping kebutuhan akan afeksi (kebutuhan akan kasih sayang), inklusi (kebutuhan akan kepuasan), dan kontrol (kebutuhan akan pengawasan). Pemenuhan kebutuhankebutuhan hidup tersebut nantinya akan mendorong manusia untuk melakukan interaksi dengan sesamanya, baik untuk mengadakan kerjasama (cooperation) ataupun untuk melakukan persaingan (competition). Kegitan komunikasi tersebut dilakukan sebagai upaya memenuhi kebutuhan bersekutu dengan orang lain. Pemenuhan kebutuhan ini guna mengembangkan diri menjadi makhluk sosial dan pribadi yang lengkap serta untuk menjamin kelagsungan hidup yang memerlukan banyak hal, seperti kebutuhan sandang, pangan, papan, hiburan, pendidikan dan kebutuhan-kebutuhan lainnya (Tubiyono, 2010). Kemampuan berkomunikasi sangat penting dimiliki oleh individu, dalam masalah ini adalah siswa SMP Shafta Surabaya.

Beberapa sekolah di Indonesia ada yang mengelompokkan siswanya dalam kelas unggulan dan kelas reguler. Kelas unggulan adalah kelas yang dirancang untuk sejumlah siswa yang memiliki kemampuan, bakat, kreativitas dan prestasi yang menonjol dibandingkan dengan siswa lainnya kemudian diberi program pengajaran yang sesuai dengan kurikulum yang dikembangkan dan adanya tambahan materi pada mata pelajaran tertentu. Kelas reguler adalah kelas yang sama seperti pada umumnya dengan kemampuan siswa dan cara pembelajaran yang sama rata sehingga secara umumnya sangat berbeda dengan kelas unggulan. Keefektifan hubungan interpersonal tergantung pada keterampilan siswa saat hubungan sosial berlangsung. Siswa kelas unggulan merasa dirinya lebih unggul dibanding siswa kelas reguler. Hal ini yang menyebabkan perbedaan kemampuan yang dimiliki oleh siswa kelas unggulan dan reguler.

Siswa menghabiskan waktu mereka bertahun-tahun di sekolah sebagai bagian anggota dari suatu masyarakat kecil 
dimana terdapat beberapa tugas untuk diselesaikan, orang-orang yang perlu mereka kenal maupun mengenal diri mereka sendiri. Pengalaman yang diperoleh individu di masyarakat ini memiliki pengaruh yang besar dalam perkembangan identitasnya, keyakinan terhadap komepentensi diri sendiri, gambaran hidup dan kesempatan meraih cita-cita, terutama hubungan sosial, batasan mengenai hal yang benar dan salah, serta pemahaman mengenai bagaimana sistem sosial diluar lingkup keluarga berfungsi (Santrock, 2004).

Tugas perkembangan merupakan suatu tugas yang akan dilalui pada periode tertentu. Tugas-tugas perkembangan berkaitan dengan sikap, perilaku dan keterampilan yang dimiliki oleh individu tersebut sesuai dengan fase atau usia perkembangannya. Kay (Yusuf, 2004) mengemukan bahwa salah satu tugas dalam fase perkembangan remaja adalah mengembangkan keterampilan komunikasi interpersonal dan belajar bergaul dengan teman sebaya atau bahkkan dengan orang lain, baik secara individual maupun berkelompok. Perkembangan remaja terjadi dalam konteks sosial yang meliputi keluarga, kelompok, teman sebaya dan lingkungan masyarakat dimana siswa itu hidup. Siswa dalam perkembangannya mempunyai kebutuhan kuat untuk berkomunikasi dan keinginan untuk mempunyai banyak teman, namun terkadang untuk membangun hubungan antar teman itu sendiri tidaklah mudah, individu tersebut harus memiliki penerimaan diri yang baik agar terciptanya suatu hubungan yang baik dan sehat antara diri sendiri dan orang lain.

Kemampuan untuk dapat berkomunikasi secara efektif sangat dituntut pada siswa sebagai calon pemimpin bangsa dan intelektual muda. Komunikasi juga merupakan salah satu alat untuk berinteraksi antar individu yang menyentuh segala aspek kehidupan kita. Siswa SMP dipersiapkan untuk menjadi generasi yang siap menghadapi era dimana dihadapkan pada situasi belajar yang menuntut mereka lebih mandiri aktif dan berinisiatif, agar dapat berinteraksi antar pribadi sehingga siswa dapat membentuk sikap saling pengertian, menumbuhkan persahabatan, memelihara kasih sayang serta menyebarkan penetahuan.

Siswa SMP perlu diberi bekal sehingga dapat berkembang dengan baik. salah satunya melalui sekolah yang merupakan proses pengembangan berbagai kemampuan dan sikap. Salah satu kemampuan yang perlu dikembangkan adalah kemampuan komunikasi interpersonal. Hal ini merupakan aspek yang penting dalam kehidupan karena setiap individu tidak terlepas dari kegiatan komunikasi dan interaksi dengan orang lain. komunikasi penting terhadap penciptaan konsep diri, aktualisasi diri untuk kelangsungan hidup, memperoleh kebahagiaan, dan terhindar dari tekanan.

Keefektifan komunikasi interpersonal jika individu yang berkomunikasi dapat memiliki kesamaan makna mengenai isi komunisi yang disampaikan, dan komunikasi dapat berlanjut. Komunikasi yang tidak efektif menjadikan tujuan awal berkomunikasi tidak dapat tercapai karena informasi atau gagasan yang disampaikan tidak diterima dengan baik oleh komunikan. Namun pada penerapannya masih banyak siswa yang kurang mampu melakukan komunikasi interpersonal yang efektif.

Keterampilan komunikasi interpersonal pada siswa seringkali dihadapi dengan hal-hal yang mengharuskan mereka menyatakan pendapat pribadinya tanpa disertai emosi atau marah dan sikap kasar, bahkan siswa harus bisa menetralisasi keadaan apabila terjadi suatu konflik. Packard (dalam Budiamin, 2006) menyatakan bahwa apabila seorang individu mengalami kegagalan dalam melakukan komunikasi interpersonal dengan individu atau kelompok lain, maka 
ia akan menjadi agresif, senang berkhayal, sakit fisik maupun mental, serta ingin lari dari lingkungannya. Menurut Tedjasaputra (2005), siswa yang memiliki kesulitan dalam melakukan komunikasi interpersonal akan mengalami kesulitan dalam menyesuaiakan diri dengan sekitarnya, sering marah, cenderung memaksakan kehendak, egois dan mau menang sendiri sehingga mudah terlibat dalam perselisihan.

Keterampilan komunikasi interpersonal pada siswa menjadi sangat penting karena dalam bergaul dengan teman sebayanya, siswa seringkali dihadapkan dengan hal-hal yang membuatnya harus mampu menyatakan pendapat pribadinya tanpa disertai emosi, marah dan perilaku kasar lainnya. Siswa harus mencoba menetralisasi keadaan apabila dihadapkan dengan suatu masalah atau konflik. Dalam suatu studi menyimpulkan bahwa kelemahan berkomunikasi akan berpengaruh menghambat personal seseorang (Slamet, 2005). Pendapat tersebut menjelaskan bahwa komunikasi interpersonal berdampak cukup besar terutama bagi kehidupan siswa.

Studi pendahuluan dikelas reguler dan unggulan tahun ajaran 2011-2012 SMP Shafta Surabaya yang dilakukan melalui wawancara dengan guru BK dan wawancara terhadap beberapa siswa reguler dan unggulan. Berdasarkan wawancara dengan guru BK dan beberapa siswa SMP Shafta Surabaya, dapat ditemui beberapa siswa memiliki komunikasi interpersonal yang cenderung kurang baik, hal ini dapat dilihat dari pendapat guru BK dari keseharian antar siswa dalam berkomunikasi interpersonal.

Menurut hasil pengamatan di kelaskelas reguler saat siswa berkomunikasi dengan teman sebayanya, beberapa perkelahian terjadi dikarenakan kesalahpahaman. Perselesihan terjadi dikarenakan kurang mampu dalam menangkap dan menginterpretasi inti dari komunikasi.
Masih ada siswa di kelas reguler yang introvert sehingga dikucilkan oleh temantemannya, tidak berani mengungkapkan gagasan-gagasan dan sulit memahami halhal yang diungkapkan oleh orang lain. Mereka cenderung mengeluarkan kata-kata kurang baik yang disebabkan karena pukulan buku dan saling mendorong kepala lawan bicaranya. Akibat dari sikap seperti itu, terjadi suatu perselisihan dan perkelahian diantara siswa tersebut. Berdasarkan hasil wawancara dengan beberapa siswa setempat bahwa komunikasi interpersonal memiliki dampak yang cukup besar bagi kehidupan siswa, namun masih banyak ditemukan kelemahan siswa dalam berkomunikasi seperti kurangnya berempati dalam berkomunikasi, dan suka membeda-bedakan teman. Siswa juga cenderung memaksakan kehendak, egois dan mengejek lawan bicaranya dalam berkomunikasi.

Hal yang sebaliknya terjadi di kelas unggulan dimana mayoritas dari siswa unggulan cukup dikenal baik oleh guruguru setempat. Banyak murid yang cukup popular dimana hampir semua siswa dan guru mengenal siswa tersebut baik dalam bidang mata pembelajaran hingga dalam bersosialisasi. Hal tersebut tentu ada hubungannya dengan komunikasi interpersonal mereka, baik dalam jam belajar mengajar maupun dalam hal bersosialisasi antar individu.

Siswa yang memiliki keterampilan komunikasi yang baik tentu akan dapat menyampaikan pendapat dan suara mereka yang dapat diterima oleh individu lain dengan baik sehingga siswa tersebut tentunya akan mendapatkan prestasi yang baik juga dalam bidang akademik. Siswa yang memiliki kemampuan komunikasi interpersonal yang baik juga akan berhasil dalam hal bersosialisasi dengan lingkungan sekitar. Mereka akan memiliki banyak teman karena pada dasarnya siswa dalam perkembangannya mempunyai kebutuhan yang kuat untuk berkomunikasi dan 
berkeinginan mempunyai banyak teman, sehingga kemampuan mereka dalam hal ini dapat meningkatkan percaya diri siswa dalam berhubungan satu sama lain. Siswa akan lebih percaya diri dalam mengembangkan potensi mereka dalam bidang akademik maupun dalam bidang lainnya.

Rendahnya kemampuan komunikasi interpersonal antar siswa sering dijumpai disekolah yang ditunjukkan dalam bentuk perilaku, seperti rendah diri, agresifitas, mencari rasa aman pada berbagai bentuk mekanisme pertahanan diri, melanggar tata tertib, menentang guru, berkelahi, tidak melaksanakan tugas sekolah, mengisolasi diri dan sulit bekerja sama dalam situasi kelompok, seringkali mempermasalahakan hal yang biasa dan wajar didalam kelas. Fenomena-fenomena tersebut hampir selalu penulis dengar dari hasil wawancara dengan guru BK.

Berdasarkan kondisi permasalahan yang terjadi di SMP Shafta Surabaya, peneliti tertarik untuk melakukan penelitian yang berjudul "Perbedaan Kemampuan Komunikasi Interpersonal Siswa Kelas Reguler dengan Siswa Kelas Unggulan Di SMP Shafta Surabaya".

\section{Metode}

Rancangan penelitian ini menggunakan metode penelitian kuantitatif dimana metode penelitian yang dilakukan dengan mengumpulkan jawaban dari responden atau pertanyaan yang merupakan pengukuran dari variabel yang diteliti dengan menggunakan analisis komparasi.

Jumlah populasi penelitian ini berjumlah 385 siswa kelas 7,8,9 unggulan dan reguler di SMP Shafta Surabaya. Penelitian ini mengambil beberapa perwakilan orang dari populasi yang ada (sampel) menggunakan teknik simple random sampling. Teknik sampling ini mengambil secara acak tanpa memperhatikan strata (tingkatan) dalam anggota populasi dikarenakan populasi dianggap homogen. Penggunaan teknik pengambilan sampel ini menggunakan rumus dari Solvin, lalu didapatkan jumlah sampel dalam penelitian sebanyak 196 dari kelas satu, dua, dan tiga. Subjek dikelompokkan menjadi dua kelompok, 66 siswa unggulan dalam satu kelompok dan 130 siswa reguler dikelompok lainnya.

Instrumen pada penelitian ini menggunakan satu skala yaitu skala kemampuan komunikasi interpersonal. Skala ini digunakan untuk mengukur kemampuan komunikasi interpersonal. skala kemampuan komunikasi interpersonal diberikan kepada sampel penelitian yaitu siswa kelas satu,dua, dan tiga di SMP Shafta Surabaya.

Teknik analisis data yang digunakan dalam penelitian ini adalah uji Independent Sample Test (uji-t). Uji-t dalam penelitian untuk mengukur apakah ada perbedaan antar sampel. Uji perbandingan mean dilakukan setelah uji-t untuk mencari perbedaan nilai rata-rata pada variabel kemampuan komunikasi interpersonal siswa unggulan dan reguler.

\section{Hasil dan Pembahasan}

Hasil pengujian hipotesis dengan menggunakan uji menggunakan uji Independent Sample Test (uji-t) yakni terdapat $\mathrm{p}>0,05$, yakni sebesar $\mathrm{p}=0,027$ dengan nilai t sebesar 2,226 yang artinya, ada perbedaan kemampuan komunikasi interpersonal siswa kelas unggulan dan reguler di SMP Shafta Surabaya. Kesimpulan ini diperoleh dari hasil uji-t penelitian ini menunjukkan adanya perbedaan nilai rata-rata (mean) pada variabel komunikasi interpersonal siswa unggulan sebesar 115,86 dan pada siswa reguler sebesar 112,32. Berdasarkan hasil tersebut menunjukkan bahwa kemampuan komunikasi interpersonal pada siswa unggulan lebih tinggi dari pada siswa reguler.

Karakteristik siswa kelas unggulan lebih percaya diri dan aktif untuk berhubungan dengan siswa kelas baik 
dalam kelas maupun dengan kelas reguler lainnya. Jika dibandingkan dengan siswa kelas reguler memiliki karakteristi tidak aktif dalam bersosialisasi dengan siswa lainnya.

Siswa kelas unggulan mendapatkan beberapa perlakuan khusus. Menurut Departemen Pendidikan dan Kebudayaan Republik Indonesia (1994) kelas unggulan memiliki beberapa ciri diantaranya; peserta yang diseleksi secara baik dengan menggunakan criteria dan prosedur tertentu, jumlah jam waktu belajar di sekolah yang lebih lama dibandingkan dengan kelas pada umumnya, sarana dan prasarana yang lebih menunjang untuk memenuhi belajar peserta didik baik dalam kegiatan intra maupun eksra kurikuler, guru dan tenaga pengajar yang unggul dan profesional, buku belajar dan soal latihan yang lebih menunjang dan jumlah siswa dikelas maksimal sampai 20 siswa sehingga dapat lebih efektif. Berdasarka dari berbagai ciri diatas dapat dilihat beberapa perbedaan perlakuan dari sistem pengajaran hingga fasilitas yang diberikan pada kelas unggulan berdampak pada kemampuan komunikasi interpersonal siswanya.

Berdasarkan hasil studi lapangan yang dilakukan peneliti sebelumnya juga menguatkan hasil penelitian. Menurut hasil pengamatan di kelas-kelas reguler saat siswa berkomunikasi dengan teman sebayanya, beberapa perkelahian terjadi dikarenakan kesalahpahaman. Perselesihan terjadi dikarenakan kurang mampu dalam menangkap dan menginterpretasi inti dari komunikasi. Salah satu karakteristik yang harus dimiliki oleh siswa untuk menunjukkan bahwa kemampuan komunikasi interpersonal mereka tinggi diantaranya adalah persepsi interpersonal, dimana peserta komunikasi yang salah memeberi makna terhadap pesan akan mengakibatkan kegagalan dalam komunikasi (Rakhmat, 2004).
Terdapat siswa di kelas reguler yang introvert sehingga dikucilkan oleh temantemannya, tidak berani mengungkapkan gagasan-gagasan dan sulit memahami halhal yang diungkapkan oleh orang lain. Hal tersebut tentu menunjukkan lemahnya kemampuan komunikasi interpersonal, dimana peserta komunikasi seharusnya memiliki hubungan interpersonal yang baik. Menurut Rakhmat (2007) hubungan interpersonal yang baik akan menumbuhkan derajat keterbukaan orang untuk mengungkapkan dirinya, makin cermat persepsinya tentang orang lain dan persepsi dirinya, sehingga makin efektif komunikasi yang berlangsung di antara peserta komunikasi. Rakhmat memberi catatan bahwa terdapat tiga faktor dalam komunikasi interpersonal yang menumbuhkan hubungan interpersonal yang baik, yaitu: percaya diri, sikap suportif dan sikap terbuka. Jika siswa reguler memiliki karakteristik diatas pastinya tidak akan ada siswa yang tertutup (introvert) atau siswa yang dikucilkan karena tidak mampu mengungkapkan gagasan-gagasan tentang dirinya kepada orang lain, sikap kurang percaya diri dan sikap terbuka.

Siswa reguler cenderung mengeluarkan kata-kata kurang baik yang disebabkan karena pukulan buku dan saling mendorong kepala lawan bicaranya. Akibat dari sikap seperti itu, terjadi suatu perselisihan dan perkelahian diantara siswa tersebut. Berdasarkan fenomena yang terjadi dilapangan, perlunya sikap positif sebagai aspek untuk kemampuan komunikasi interpersonal yang baik. Menurut DeVito (2007), berkomunikasi secara positif di dalam komunikasi interpersonal sekurang-kurangnya melalui dua jalan, yaitu berdasarkan sikap positif dan menghargai orang lain. Perasaan-perasaan negatif biasanya membuat komunikasi menjadi lebih sulit dan dapat menyebabkan perpecahan atau konflik.

Berdasarkan hasil wawancara dengan beberapa siswa setempat bahwa komuni- 
kasi interpersonal memiliki dampak yang cukup besar bagi kehidupan siswa, namun masih banyak ditemukan kelemahan siswa dalam berkomunikasi seperti kurangnya berempati dalam berkomunikasi, dan suka membeda-bedakan teman. Siswa juga cenderung memaksakan kehendak, egois dan mengejek lawan bicaranya dalam berkomunikasi. Ada beberapa persyaratan yang harus terpenuhi siswa agar terhindarnya kejadian-kejadian seperti diatas. Menurut DeVito (2007) menyebutkan ada 10 aspek kemampuan komunikasi interpersonal yang baik, diantaranya keterbukaan, empati, dukungan, sikap positif, kesamaan, keyakinan, kesiapan, manajemen interaksi, sikap ekspresif, dan orientasi pada orang lain. Siswa reguler sangat terlihat memeliki kelemahan dalam aspek tersebut sehingga kemampuan komunikasi mereka lebih rendah bila dibandingkan dengan siswa unggulan.

Hal yang sebaliknya terjadi di kelas unggulan dimana mayoritas dari siswa unggulan cukup dikenal baik oleh guruguru setempat. Banyak murid yang cukup populer dimana hampir semua siswa dan guru mengenal siswa tersebut baik dalam bidang mata pembelajaran hingga dalam bersosialisasi. Hal tersebut tentu ada hubungannya dengan komunikasi interpersonal mereka, baik dalam jam belajar mengajar maupun dalam hal bersosialisasi antar individu. Siswa yang memiliki keterampilan komunikasi yang baik tentu akan dapat menyampaikan pendapat dan suara mereka yang dapat diterima oleh individu lain dengan baik sehingga siswa tersebut tentunya akan mendapatkan prestasi yang baik juga dalam bidang akademik. Siswa yang memiliki kemampuan komunikasi interpersonal yang baik juga akan berhasil dalam hal bersosialisasi dengan lingkungan sekitar. Mereka akan memiliki banyak teman karena pada dasarnya siswa dalam perkembangannya mempunyai kebutuhan yang kuat untuk berkomunikasi dan berkeinginan mempu- nyai banyak teman, sehingga kemampuan mereka dalam hal ini dapat meningkatkan percaya diri siswa dalam berhubungan satu sama lain. Siswa akan lebih percaya diri dalam mengem-bangkan potensi mereka dalam bidang akademik maupun dalam bidang lainnya.

Adanya perbedaan kelas reguler dan unggulan juga membuat mereka kurang mampu bersosialisasi antar siswa dan kelas. Menurut dari guru BK mengenai siswa unggulan bila dibandingkan dengan siswa reguler, siswa reguler cenderung lebih tertutup. Mereka lebih sering menghabiskan waktu dengan teman sekelas mereka atau teman dekat mereka dan jarang bergaul dengan siswa lainnya yang berada diluar kelas mereka. Menurut pendapat guru BK, banyak faktor yang mempengaruhi hal tersebut diantaranya terjadi perbedaan mulai dari tenaga pengajar untuk kelas unggulan dan reguler, jam pelajaran yang lebih banyak dan lebih kompleks juga hanya didapati oleh kelas unggulan. Kelas unggulan akan mendapatkan pendidikan yang berbeda dibanding kelas reguler. Pelajaran tambahan yang sering diberikan kepada kelas unggulan juga menambah waktu bersosialisai siswa di sekolah sehingga hal tersebut secara tidak langsung akan berpengaruh terhadap kemampuan komunikasi interpersonal mereka. Sistem pembelajaran yang diterima oleh kelas unggulan maupun kelas regaler juga berbeda, dimana kelas unggulan mendapat fasilitas pembelajaran yang lebih lengkap dan perhatian yang lebij khusus dari tim pengajar. Hal yang berbanding terbalik terjadi pada siswa yang berada di kelas reguler. Siswa unggulan cenderung bebas dalam bersosialisasi dengan teman baik didalam maupun diluar kelas mereka. Hal diatas tentu menunjukkan perbedaan pemberian perlakuan terhadap kelas unggulan dan reguler tentu akan berpengaruh terhadap sikap dan perilaku siswanya dalam kemampuan komunikasi interpersonal mereka. 
Siswa dalam perkembangannya mempunyai kebutuhan yang kuat untuk berkomunikasi dan keinginan untuk mempunyai banyak teman, namun kadangkadang untuk membangun hubungan antar teman itu sendiri tidak mudah, seseorang harus memiliki penerimaan diri yang baik agar tercifta suatu hubungan yang baik dan sehat. Faktor penghambat komunikasi interpersonal diantaranya sikap tidak percaya, sikap tidak suportif dan sikap tertutup. Siswa dengan kemampuan komunikasi interpersonal yang tinggi tentunya memiliki hubungan interpersonal yang lebih baik.

Penelitian ini sejalan dengan hasil penelitian sebelumnya oleh Asrowi \& Astianingrum (2013) yang menyimpulkan bahwa bimbingan teman sebaya efektif untuk meningkatkan komunikasi interpersonal siswa. Permasalahan rendahnya kemampuan komunikasi interpersonal tidak hanya dilatarbelakangi oleh berbagai faktor, sehingga untuk penelitian selanjutnya diharapkan dapat menggunakan variabel yang lebih eragam agar dapat menggunakan penelitian yang lebih lengkap dan menambah ragam pengetahuan di bidang psikologi.

\section{Simpulan}

Tujuan dari penelitian ini adalah untuk mengetahui perbedaan kemampuan komunikasi interpersonal siswa kelas unggulan dan reguler di SMP Shafta Surabaya. Hasil dari data penelitian yang dilakukan di SMP Shafta Surabaya menunjukkan adanya perbedaan yang signifikan kemampuan komunikasi interpersonal siswa kelas unggulan dan reguler, maka dapat ditarik kesimpulan bahwa hipotesis dalam penelitian ini diterima sehingga dapat disimpulkan secara keseluruhan bahwa ada perbedaan kemampuan komunikasi interpersonal siswa kelas unggulan dan reguler di SMP Shafta Surabaya. Hasil penelitian juga menunjukkan bahwa siswa unggulan memiliki kemampuan komunikasi interpersonal lebih tinggi daripada siswa reguler.

\section{Daftar Pustaka}

Agung, W. (2010). Panduan Program SPSS 17.0: Untuk Mengolah Penelitian Kuantitatif. Yogyakarta: Gerailmu.

Arikunto, S. (2006). Prosedur Penelitian (Susunan Pendekatan Praktek) Revisi VI. Jakarta: Rineka Cipta.

Asrowi, H, \& Astianingrum, Y. (2013). Bimbingan Teman , H. \& Sebaya Untuk Meningkatkan Komunikasi Interpersonal Siswa. COUNSELIUM: Jurnal Program Studi Bimbingan dan Konseling. Diakses dari http://www.jurnal.fkip.uns.ac.id/ind ex.php/counsilium/article/view/327 7, pada Januari 2015.
Azwar, S. (2010). Reliabilitas dan Validitas. Yogyakarta: Pustaka Belajar.

Budiamin, A. (2006). Perkembangan Peserta Didik. Bandung: UPI Press.

Budyatna, M. \& Ganiem, L. M. (2011). Teori Komunikasi Antarpribadi. Jakarta: Kencana

Departemen Pendidikan dan Kebudayaan. (1994). Pedoman Perpustakaan Perguruan Tinggi. Jakarta: Departemen Pendidikan dan Kebudayaan.

DeVito, J. A. (2007). The interpersonal communication book (11th ed). New York : Sage Publications Ltd. 
Effendy, Onong Uchjana. (2009). Komunikasi teori dan praktek. Bandung : PT Remaja Rosdakarya

Liliweri, Alo. (2007). Komunikasi Antarpribadi, Bandung: PT. Citra Aditya Bakti.

Marliany, R. (2010). Psikologi Umum. Bandung: CV Pustaka Setia.

Mudyahardjo. (2002). Filsafat Ilmu Pendidikan. Bandung: Remaja Rosdakarya.

Mulyana, Deddy. (2005). Ilmu Komunikasi Suatu Pengantar. Bandung: Remaja Rosdakarya.

Rakhmat, J. (2009). Psikologi Komunikasi. Bandung: PT. Remaja Rosdakarya.

Rakhmat, J. (2004). Metode Penelitian Komunikasi. Bandung: PT. Remaja Rosdakarya.

Sobur. A. (2011). Psikologi Umum. Bandung: CV Pustaka Setia.

Southern, W.T. and Jones, E.D., (1991). The Academic Acceleration of Gifted Children. New York: Teachers College Press.

Sugiyono. (2006). Metode Penelitian Kuantitatif. Bandung: Alfabeta.

Suranto A.W. (2011). Komunikasi Interpersonal. Yogyakarta: Media Wacana.
Sugiyono. (2007). Statistik untuk peneliti. Bandung: CV. Alfabeta.

Syah, Muhibin. (2006). Psikologi Belajar. Jakarta: PT. Raja Grafindo Persada.

Silalahi, Aripin. (2006). Program Kelas Unggulan. Jakarta: Sidikalang.

Supriyono, Agus. (2009). Penyelenggaraan Program Kelas Unggulan di Sekolah. Surakarta: Universitas Sebelas Maret.

Tedjasaputra, M.S. (2005). Bermain, Mainan, dan Permainan. Jakarta : Grasindo Trianto.

Tri, A. C. 2006. Psikologi Belajar. Semarang: Unnes Press.

Widyastono, Herry. (2004). Pendidikan Pembelajaran Kooperatif dan Kompetitif. Jakarta : Direktorat Pendidikan Luar Biasa Ditjen Dikdasmen Depdiknas, Unversitas Indonesia.

Winarsunu, Tulus. (2006). Statistik Dalam Penelitian Psikologi Dan Pendidikan. Malang: UMM Press.

Yusuf, Syamsu. (2004), Psikologi Perkembangan Anak dan Remaja. Bandung: Remaja Rosdakarya

Yusuf, S. (2009). Program Bimbingan dan Konseling di Sekolah. Bandung: Rizqi Press. 